\title{
Palladium-catalyzed formal arylacylation of allenes employing acid chlorides and arylboronic acids.
}

\author{
$\operatorname{AUTHOR}(S):$ \\ Tatsumi, Kenta; Fujihara, Tetsuaki; Terao, Jun; \\ Tsuji, Yasushi
}

\section{CITATION:}

Tatsumi, Kenta ...[et al]. Palladium-catalyzed formal arylacylation of allenes employing acid chlorides and arylboronic acids.. Chemical Communications 2014, 50 (62): 8476-8479

\section{ISSUE DATE:}

2014-05-20

URL:

http://hdl.handle.net/2433/200258

\section{RIGHT:}

This journal is @ The Royal Society of Chemistry 2014.; この論文は出版 社版でありません。引用の際には出版社版をご確認ご利用ください。; This is not the published version. Please cite only the published version. 


\title{
COMMUNICATION
}

\section{Palladium-catalyzed formal arylacylation of allenes employing acid chlorides and arylboronic acids}

\author{
Kenta Tatsumi, Tetsuaki Fujihara, ${ }^{*}$ Jun Terao, and Yasushi Tsuji*
}

\begin{abstract}
Palladium-catalyzed formal arylacylation of allenes using acid chlorides and arylboronic acids has been achieved. The reaction afforded the corresponding $\alpha, \beta$-unsaturated ketones regio- and stereoselectively.
\end{abstract}

The addition of carbonyl compounds to carbon-carbon unsaturated bonds is an efficient method to functionalize unsaturated compounds. ${ }^{1}$ To date, the addition of aldehydes (hydroacylation), ${ }^{2}$ formamides (hydrocarbamoylation), ${ }^{3}$ formates (hydroesterification), ${ }^{4}$ and acid chlorides (chloroacylation) $^{5}$ to carbon-carbon unsaturated bonds have been reported. The addition of ketone, namely carboacylation, is also an efficient method to synthesize highly functionalized ketones. However, the activation of acyl-carbon bonds of ketones has been difficult. To achieve carboacylation, directing groups $^{6}$ or strained structures ${ }^{7,8}$ were required. Therefore, formal carboacylation using a carbon nucleophiles and a carbonyl electrophile as a ketone equivalent is desirable as an alternative method. The reactions of organometallic reagents with carbon-carbon unsaturated bonds followed by trapping with acid chlorides as the electrophile have been investigated. ${ }^{9}$ However, highly reactive organometallic reagents such as organomagnesium or organozinc reagents or the presence of directing groups in unsaturated compounds were indispensable to control the reactivity and regioselectivity. There is only one precedent to data on acylmetalation strategy; Miura et al. reported the Rh-catalyzed carboacylation of norbornene using acid anhydrides and organoboron reagents. ${ }^{10,11}$

Allenes are valuable substrates in transition-metal-catalyzed reactions. ${ }^{12}$ In particular, allenes can be easily inserted to $\mathrm{Pd}-\mathrm{C}$ bonds to form the corresponding $\pi$-allyl Pd species. ${ }^{12 a}$ Cheng and co-workers reported the acylmetalation of allenes using acid chlorides with diborane, disilane, and distannane ${ }^{13}$. Recently, we reported the formal hydroacylation of allenes using acid chlorides and hydrosilanes. ${ }^{14} \mathrm{We}$ envisioned that the use of carbon nucleophiles in place of hydrosilanes would achieve the formal carboacylation of allenes. In this paper, we describe the palladium-catalyzed formal arylacylation of allenes using acid chlorides and arylboronic acids. Notably, no directing groups were required in the present reaction and various $\alpha, \beta$-unsaturated ketones are obtained regio- and stereoselectively.
Table 1. Optimization of reaction conditions. ${ }^{a}$

\begin{tabular}{|c|c|c|c|c|}
\hline 1a & $\begin{array}{l}\mathrm{Cy}+\mathrm{PhB}(\mathrm{OH})_{2} \\
2 \mathrm{a} \quad 3 \mathrm{a}\end{array}$ & $\begin{array}{l}\text { tba })_{3}(5.0 \mathrm{~mol} \%) \\
\mathrm{Cl}(10 \mathrm{~mol} \%) \\
\mathrm{OO}_{4}(2.0 \text { equiv) } \\
2 \mathrm{O}(4.0 \text { equiv) } \\
\text { ene } / \mathrm{MeCN}=9 / 1 \\
(4.0 \mathrm{~mL}) \\
50^{\circ} \mathrm{C}, 3 \mathrm{~h}\end{array}$ & & \\
\hline Entry & Changes & $\begin{array}{l}\text { Total yield } \\
\text { of } \mathbf{4 a}(\%)^{b}\end{array}$ & $\begin{array}{c}(E)-\mathbf{4 a}: \\
\text { other } \\
\text { isomers }\end{array}$ & $\begin{array}{c}\mathbf{5} \\
(\mathrm{mmol})^{c}\end{array}$ \\
\hline 1 & standard condition & $86(80)^{d}$ & $96: 4$ & 0.034 \\
\hline 2 & without $\mathrm{Pd}_{2}(\mathrm{dba})_{3}$ & 0 & - & 0 \\
\hline 3 & addition of $\mathrm{PPh}_{3}{ }^{e}$ & 0 & - & 0.22 \\
\hline 4 & in toluene as a solvent & 62 & $88: 12$ & 0.027 \\
\hline 5 & in $\mathrm{MeCN}$ as a solvent & 0 & - & 0 \\
\hline 6 & without $\mathrm{CuCl}$ & 31 & $96: 4$ & 0.014 \\
\hline 7 & without $\mathrm{H}_{2} \mathrm{O}$ & 6 & $88: 12$ & 0.005 \\
\hline 8 & $\mathrm{H}_{2} \mathrm{O}$ (8.0 equiv) & 66 & $96: 4$ & 0.040 \\
\hline 9 & $\mathrm{PhB}(\operatorname{pin})^{f}$ & 0 & - & 0 \\
\hline 10 & $\mathrm{PhBF}_{3} \mathrm{~K}$ & 0 & - & 0.001 \\
\hline
\end{tabular}

a Reaction conditions: 3-phenypropionyl chloride (1a, 0.40 mmol), cyclohexylallene (2a, $0.20 \mathrm{mmol}$, yield and equiv are based on this amount), $\mathrm{PhB}(\mathrm{OH})_{2}$ (3a, $\left.0.30 \mathrm{mmol}\right), \mathrm{Pd}_{2}(\mathrm{dba})_{3} \cdot \mathrm{CHCl}_{3}(0.010 \mathrm{mmol}, 5.0$ mol \%), $\mathrm{CuCl}(0.020 \mathrm{mmol}, 10 \mathrm{~mol} \%), \mathrm{K}_{3} \mathrm{PO}_{4}(0.40 \mathrm{mmol}), \mathrm{H}_{2} \mathrm{O}(4.0$ equiv, $0.80 \mathrm{mmol})$ in toluene $/ \mathrm{MeCN}=9 / 1(\mathrm{v} / \mathrm{v}, 4.0 \mathrm{~mL})$, at $50{ }^{\circ} \mathrm{C}$, for $3 \mathrm{~h} .{ }^{b}$ Yield by the GC internal standard method. ${ }^{c}$ Determined by GC. ${ }^{d}$ Isolated yield of pure $(E)-\mathbf{4 a} .{ }^{e} \mathrm{P} / \mathrm{Pd}=2 .{ }^{f} \mathrm{pin}=$ pinacolato

First, the reaction of 3-phenylpropionyl chloride (1a), cyclohexylallene (2a) and phenylboronic acid (3a) was carried out in the presence of a catalytic amount of $\mathrm{Pd}_{2}(\mathrm{dba})_{3}(\mathrm{dba}=$ dibenzylideneacetone) and $\mathrm{CuCl}$ with $\mathrm{K}_{3} \mathrm{PO}_{4}$ and $\mathrm{H}_{2} \mathrm{O}$ in toluene/MeCN $(9 / 1, \mathrm{v} / \mathrm{v})$ at $50{ }^{\circ} \mathrm{C}$ (Table 1$)$. Under the standard reaction conditions (entry 1$),(E)-\mathbf{4 a}$ was obtained with high regio- and stereoselectivity (96/4). As a side product, a small amount of ketone $\mathbf{5}$, which was formed by the Suzuki-Miyaura coupling of $\mathbf{1 a}$ with $\mathbf{3 a},{ }^{15}$ was detected. Notably, styrene formation via the decarbonylation of $\mathbf{1 a}$ followed by $\beta$ hydrogen elimination was not observed. With a column 
chromatography, pure $(E)-\mathbf{4 a}$ was isolated in $80 \%$ yield. Without $\mathrm{Pd}_{2}(\mathrm{dba})_{3}$, the reaction did not proceed at all (entry 2). In this reaction, the addition of auxiliary ligands such as $\mathrm{PPh}_{3}$ inhibited the formation of $\mathbf{4 a}$ and only $\mathbf{5}$ was obtained in $73 \%$ yield $(0.22 \mathrm{mmol})$ based on 3a (entry 3$)$. When MeCN was removed from the reaction system (only toluene was used as the solvent), both the yield and selectivity decreased considerably (entry 4). In contrast, the use of $\mathrm{MeCN}$ as the solvent did not afford $\mathbf{4 a}$ at all (entry 5). In the Suzuki-Miyaura coupling, it was known that the addition of a $\mathrm{Cu}$ salt promotes the coupling reaction. ${ }^{15 \mathrm{~d}, 16}$ Thus, without $\mathrm{CuCl}$, the yield of $\mathbf{4 a}$ decreased to $31 \%$ (entry 6). The addition of $\mathrm{H}_{2} \mathrm{O}$ was also found to be important in this reaction; the yield of $\mathbf{4 a}$ was very low in the absence of $\mathrm{H}_{2} \mathrm{O}$ (entry 7). In contrast, when the amount of $\mathrm{H}_{2} \mathrm{O}$ was increased to 8.0 equiv $(1.6 \mathrm{mmol})$, the yield of $4 \mathbf{a}$ decreased and that of 5 increased (entry 8; cf. entry 1). The use of $\mathrm{PhB}(\mathrm{pin})$ or $\mathrm{PhBF}_{3} \mathrm{~K}$ instead of $\mathrm{PhB}(\mathrm{OH})_{2}$ did not afford $4 \mathbf{a}$ at all (entries 9 and 10).

Various acid chlorides reacted with 2a and 3a (Table 2). The reactions of aliphatic acid chlorides $(\mathbf{1} \mathbf{b}-\mathbf{g})$ gave the corresponding products $(\mathbf{4 b}-\mathbf{4 g})$ in good to high yields (entries 1-6). Ether (entry 3) and ester (entry 4) functional groups were tolerated in the reaction. In the case of cyclohexanecarbonyl chloride (1f), the desired product was obtained in a moderate yield in the presence of 8.0 equiv of $\mathrm{H}_{2} \mathrm{O}$ (entry 5). In general, less reactive acid chlorides 1 tend to require comparatively more amount of $\mathrm{H}_{2} \mathrm{O}$ to ensure good yields. The reaction with

Table 2. Scope of acid chlorides. ${ }^{a}$

Entry

${ }^{a}$ Reaction conditions: acid chloride $(\mathbf{1}, 0.40 \mathrm{mmol}), \mathbf{2 a},(0.20 \mathrm{mmol}$, yield and equiv are based on this amount), $\mathbf{3 a}(0.30 \mathrm{mmol}), \mathrm{Pd}_{2}(\mathrm{dba})_{3} \cdot \mathrm{CHCl}_{3}$ (0.010 mmol, $5.0 \mathrm{~mol} \%), \mathrm{CuCl}(0.020 \mathrm{mmol}, 10 \mathrm{~mol} \%), \mathrm{K}_{3} \mathrm{PO}_{4}(0.40$ $\mathrm{mmol}$ ), $\mathrm{H}_{2} \mathrm{O}$ (x equiv) in toluene/MeCN $=9 / 1(\mathrm{v} / \mathrm{v}, 4.0 \mathrm{~mL})$, at $50{ }^{\circ} \mathrm{C}$, for 3 h. ${ }^{b}$ Isolated yield of $(E)-\mathbf{4 b}-\mathbf{j} .{ }^{c}$ Mixture of isomers $(E / Z=87 / 13)$.
Table 3. Scope of allenes. ${ }^{a}$

Entry

${ }^{a}$ Reaction conditions: 1a $(0.40 \mathrm{mmol})$, allene $(\mathbf{2}, 0.20 \mathrm{mmol}$, yield and equiv are based on this amount), 3a $(0.30 \mathrm{mmol}), \mathrm{Pd}_{2}(\mathrm{dba})_{3} \cdot \mathrm{CHCl}_{3}$ (0.010 mmol, $5.0 \mathrm{~mol} \%), \mathrm{CuCl}(0.020 \mathrm{mmol}, 10 \mathrm{~mol} \%), \mathrm{K}_{3} \mathrm{PO}_{4}(0.40$ mmol), $\mathrm{H}_{2} \mathrm{O}$ (x equiv) in toluene/MeCN $=9 / 1\left(\mathrm{v} / \mathrm{v}, 4.0 \mathrm{~mL}\right.$ ), at $50{ }^{\circ} \mathrm{C}$, for 3 h. ${ }^{b}$ Isolated yield of $(E)-\mathbf{4 k}-\mathbf{p} .{ }^{c} \mathbf{3 a}(0.40 \mathrm{mmol})$.

pivaroyl chloride afforded the $E / Z$ mixture of the products in moderate yield with a ratio of $E / Z=87 / 13$ (entry 6). Benzoyl chloride derivatives $(\mathbf{1} \mathbf{h}-\mathbf{j})$ with electron-donating (1i) and electron-withdrawing substituents (1j) afforded the corresponding products in good yields (entries 7-9).

Next, various allenes were reacted with $1 \mathbf{a}$ and $\mathbf{3 a}$ in the presence of suitable amounts of $\mathrm{H}_{2} \mathrm{O}$ (Table 3). Although the reaction of $\mathbf{2 b}$ with a primary alkyl group gave the product $(\mathbf{4 k})$ in moderate yield (entry 1), those of $\mathbf{2 c}$ and $\mathbf{2 d}$ bearing a secondary and a tertiary alkyl group afforded the corresponding products (4I and $\mathbf{4 m}$ ) in high yields (entries 2 and 3). The reaction of phenylallene (2e) gave $4 \mathbf{n}$ in a low yield (entry 4). 1,1-Disubstituted (2f) and 1,3-disubstituted (2g) allenes successfully gave the corresponding products (4o and $\mathbf{4 p})$ in high yields (entries 5 and 6 ).

Various arylboronic acids (3) afforded the corresponding $\alpha, \beta$-unsaturated ketones (4) in high yields (Table 4 ). In the case of a reactive arylboronic acid bearing the electron-donating substituent $(\mathbf{3 b})$, the corresponding product was obtained in $82 \%$ yield in the presence of a smaller amount (2.0 equiv) of $\mathrm{H}_{2} \mathrm{O}$ (entry 1). On the other hand, more $\mathrm{H}_{2} \mathrm{O}$ (5-9 equiv) was beneficial to realize high yields with less reactive $3 \mathbf{c}-\mathbf{g}$ bearing electron-withdrawing substituents (entries 2-6). Under the reaction conditions, chloro (3d), bromo (3e), cyano (3f), and methoxycarbonyl (3g) functionalities on the phenyl rings remained intact (entries 3-6). The reaction of 1-naphtylboronic acid (3h) also afforded the product in $89 \%$ yield (entry 7 ). More reactive $(E)$-styrylboronic acid (3i) gave the corresponding product $(\mathbf{4 x})$ in a moderate yield, even without the addition of $\mathrm{CuCl}$ to the catalyst system.

A plausible catalytic cycle is shown in Scheme 1. First, the oxidative addition of an acid chloride (1) to $\operatorname{Pd}(0)$ species $\mathbf{A}$ 
Table 4. Scope of Boronic acids ${ }^{a}$.

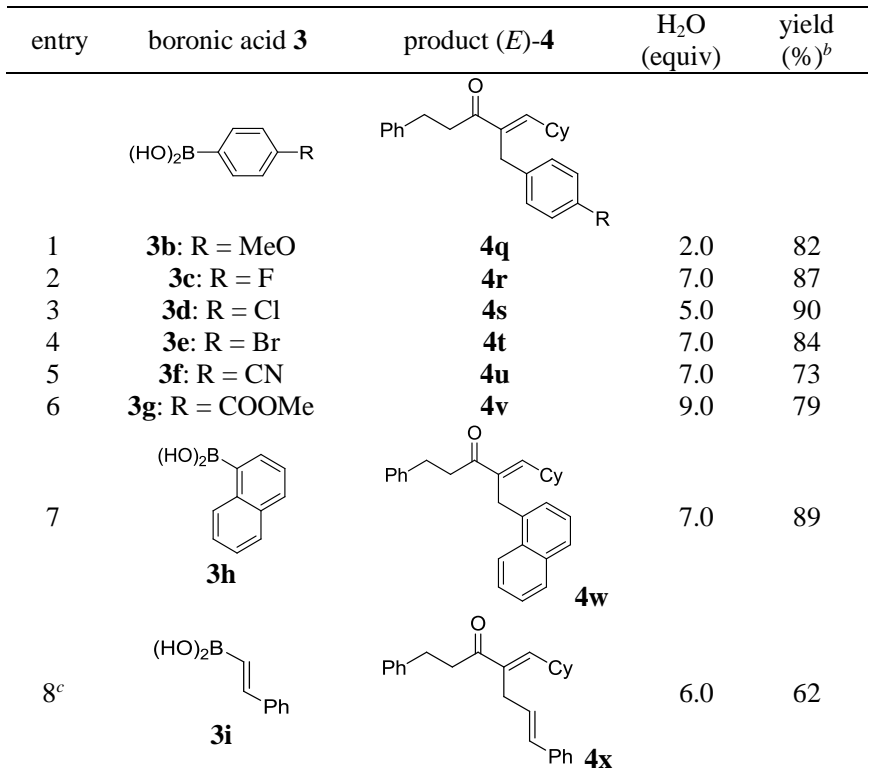

${ }^{a}$ Reaction conditions: 1a $(0.40 \mathrm{mmol}), \mathbf{2 a}(0.20 \mathrm{mmol}$, yield and equiv are based on this amount), boronic acid $(\mathbf{3}, 0.30 \mathrm{mmol}), \mathrm{Pd}_{2}(\mathrm{dba})_{3} \cdot \mathrm{CHCl}_{3}$ $(0.010 \mathrm{mmol}, 5.0 \mathrm{~mol} \%), \mathrm{CuCl}(0.020 \mathrm{mmol}, 10 \mathrm{~mol} \%), \mathrm{K}_{3} \mathrm{PO}_{4}(0.40$ $\mathrm{mmol}$ ), $\mathrm{H}_{2} \mathrm{O}$ (x equiv) in toluene $/ \mathrm{MeCN}=9 / 1\left(\mathrm{v} / \mathrm{v}, 4.0 \mathrm{~mL}\right.$ ), at $50^{\circ} \mathrm{C}$, for 3 h. ${ }^{b}$ Isolated yield of $(E)-\mathbf{4 q}-\mathbf{x} .{ }^{c}$ Two equiv of $\mathbf{3 i}$ was used without $\mathrm{CuCl}$.

affords an acylpalladium species B (step a). Next, the fast insertion of an allene (2) to $\mathbf{B}$ instead of the transmetalation with 3 (step $b^{\prime}$ ) or decarbonylation (step b") gives a $\pi$ allylpalladium intermediate $\mathbf{C}$ (step $b$ ). The transmetalation of aryl boronic acid (3) with $\mathbf{C}$ in presence of a base and $\mathrm{CuCl}$ affords an arylpalladium species $\mathbf{D}$ (step c). Finally, the reductive elimination of $\mathbf{D}$ provides the $\alpha, \beta$-unsaturated ketone (4) and regenerates the palladium(0) species $\mathbf{A}$ (step d). Water must play an important role to activate boronic acid and/or Pd catalyst species. ${ }^{15 c, 17}$ In the present formal arylacylation, the adducts can be efficiently and selectively obtained by simply adjusting the amount of $\mathrm{H}_{2} \mathrm{O}$ depending on reactivity of substrates.

\section{Notes and references}

Department of Energy and Hydrocarbon Chemistry, Graduate School of Engineering, Kyoto University, Kyoto 615-8510, Japan.

E-mail: tfuji@scl.kyoto-u.ac.jp, ytsuji@scl.kyoto-u.ac.jp; Fax: +81-75383-2514; Tel: +81-75-383-2515

$\dagger$ Electronic Supplementary Information (ESI) available. See DOI: $10.1039 / \mathrm{c} 000000 \mathrm{x} /$

1 For a review, see: T. Fujihara, T. Iwai, J. Terao and Y. Tsuji, Synlett, 2010, 2537.

2 For reviews, see: (a) M. C. Willis, Chem. Rev., 2010, 110, 725; (b) J. C. Leung and M. J. Krische, Chem. Sci., 2012, 3, 2202; (c) Y. J. Park, J.-W. Park and C.-H. Jun, Acc. Chem. Res., 2008, 41, 222; (d) G. C. Fu, In Modern Rhodium-Catalyzed Organic Reactions; A. Evans, Ed.;Wiley-VCH: Weinheim, 2005; pp79.

3 Recent examples of hydrocarbamoylation, see: (a) T. Fujihara, Y Katafuchi, T. Iwai, J. Terao and Y. Tsuji, J. Am. Chem. Soc., 2010, 132, 2094; (b) B. Li, Y. Park and S. Chang, J. Am. Chem. Soc., 2014, 136, 1125; (c) P. A. Donets and N. Cramer, J. Am. Chem. Soc., 2013, 135, 11772; (d) N. Armanino, and E. M. Carreira, J. Am. Chem. Soc., 2013, 135, 6814; (e) Y. Nakao, H. Idei, K. S. Kanyiva and T. Hiyama, J. Am. Chem. Soc., 2009, 131, 5070.

4 Recent examples of hydroesterification, see: (a) Y. Katafuchi, T. Fujihara, T. Iwai, J. Terao and Y. Tsuji, Adv. Synth. Catal., 2011, 353,
Scheme 1. Plausible mechanism.

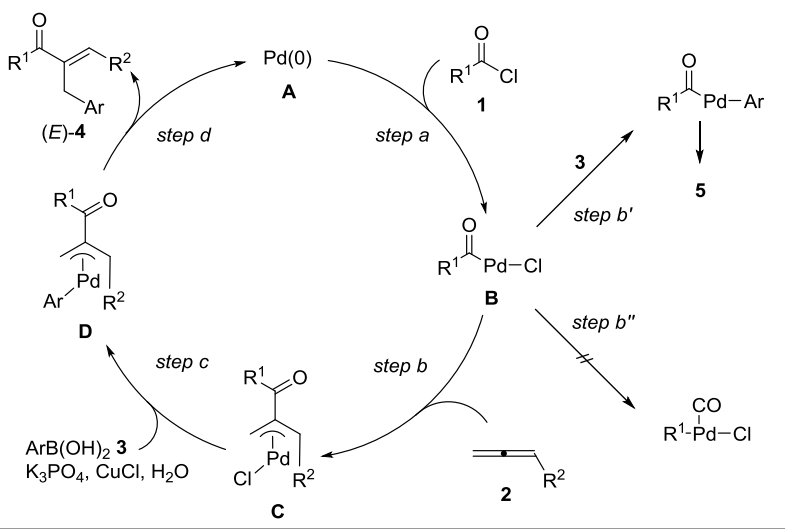

475; (b) B. Li, S. Lee, K. Shin and S. Chang, Org. Lett., 2014, 16 2010; (c) I. Fleischer, R. Jennerjahn, D. Cozzula, R. Jackstell, R. Franke and M. Beller, ChemSusChem, 2013, 6, 417; $(d)$ H. Konishi, T. Ueda, T. Muto and K. Manabe, Org. Lett., 2012, 14, 4722;

5 Recent examples of chloroacylation, see: (a) T. Iwai, T. Fujihara, J. Terao and Y. Tsuji, J. Am. Chem. Soc., 2012, 134, 1268; (b) T. Iwai, T. Fujihara, J. Terao and Y. Tsuji, J. Am. Chem. Soc., 2010, 132, 9602; (c) R. Cano, M. Yus and D. J. Ramon, Tetrahedron, 2013, 69, 7056.

6 (a) A. M. Dreis and C. J. Douglas, J. Am. Chem. Soc., 2008, 131, 412; (b) M. T. Wentzel, V. J. Reddy, T. K. Hyster and C. J. Douglas, Angew. Chem. Int. Ed., 2009, 48, 6121.

7 For reviews, see: $(a)$ T. Seiser, T. Saget, D. N. Tran and N. Cramer, Angew. Chem. Int. Ed., 2011, 50, 7740; (b) M. Murakami, M. Makino, S. Ashida and T. Matsuda, Bull. Chem. Soc. Jpn., 2006, 79, 1315. (c) D. Bellus and B. Ernst, Angew. Chem. Int. Ed., 1988, 27, 797.

8 For recent examples, see: (a) L. Souillart, E. Parker, N. Cramer, Angew. Chem. Int. Ed., 2014, 53, 3001; (b) T. Xu and G. Dong, Angew. Chem. Int. Ed., 2012, 51, 7567; (c) T. Xu, H. M. Ko, N. A. Savage and G. Dong, J. Am. Chem. Soc., 2012, 134, 20005; (d) L. Liu, N. Ishida and M. Murakami, Angew. Chem. Int. Ed., 2012, 51, 2485.

9 (a) L. Wang, Y. Shao and Y. Liu, Org. Lett. 2012, 14, 3978; (b) S. Ito, T. Itoh and M. Nakamura, Angew. Chem. Int. Ed., 2011, 50, 454; (c) C. Dunst, A. Metzger, E. A. Zaburdaeva and P. Knochel, Synthesis, 2011, 3453; (d) F. F. Fleming, Q. Wang and O. W. Steward, J. Org. Chem., 2003, 68, 4235; (e) K. J. MacNeil and D. J. Burton, J. Org. Chem., 1993, 58, 4411.

10 K. Oguma, M. Miura, T. Satoh and M. Nomura, J. Organomet. Chem., 2002, 648, 297.

11 Miura et al. also reported decarbonylative formal carboacylation of alkyne, see: K. Kokubo, K. Matsumasa, M. Miura and M. Nomura, $J$. Organomet. Chem., 1998, 560, 217.

12 For recent reviews, see: (a) R. Zimmer, C. U. Dinesh, E. Nandanan and F. A. Khan. Chem. Rev., 2000, 100, 3067; (b) L.-L. Wei, H. Xiong and R. P. Hsung, Acc. Chem. Res., 2003, 36, 773; (c) S. Ma, Chem. Rev., 2005, 105, 2829; (d) M. Jeganmohan and C.-H. Cheng, Chem. Commun., 2008, 3101; (e) B. Alcaide and P. Almendros, Acc. Chem. Res., 2014, 47, 939; (f) J. Ye and S. Ma, Acc. Chem. Res., 2014, 47, 989.

13 (a) F.-Y. Yang, M.-Y. Wu and C.-H. Cheng, J. Am. Chem. Soc., 2000, 122, 7122; (b) F.-Y. Yang, M. Shanmugasundaram, S.-Y. Chuang, P.-J. Ku, M.-Y. Wu and C.-H. Cheng, J. Am. Chem. Soc., 2003, 125, 12576.

14 T. Fujihara, K. Tatsumi, J. Terao and Y. Tsuji, Org. Lett., 2013, 15, 2286.

15 (a) M. Haddach and J. R. McCarthy, Tetrahedron Lett., 1999, 40, 3109; (b) N. A. Bumagin and D. N. Korolev, Tetrahedron Lett., 1999, 40, 3057; (c) Y. Urawa and K. Ogura, Tetrahedron Lett., 2003, 44, 271; (d) D. Ogawa, K. Hyodo, M. Suetsugi, J. Li, Y. Inoue, M. Fujisawa, M. Iwasaki, K. Takagi and Y. Nishihara, Tetrahedron, 2013, 69, 2565 .

16 Examples of Pd catalyzed Suzuki coupling with $\mathrm{Cu}$ salts, see (a) C. Savarin and L. S. Liebeskind, Org. Lett., 2001, 3, 2149; (b) P. B. Hodgson and F. H. Salingue, Tetrahedron Lett., 2004, 45, 685; (c) Y. 
Yamamoto, M. Takizawa, X-Q. Yu and N. Miyaura, Angew. Chem. Int. Ed., 2008, 47, 928; (d) T. Konakahara, Y. B. Kiran, Y. Okuno, R. Ikeda and N. Sakai, Tetrahedron Lett., 2010, 51, 2335.

17 B. P. Carrow and J. F. Hartwig, J. Am. Chem. Soc., 2011, 133, 2166. 